\title{
From the Desk of Editor-in-Chief
}

\section{Ramesh Chandra Sinha ${ }^{1}$}

Published online: 11 December 2019

(C) ICPR 2019

The objective of the Journal of Indian Council of Philosophical Research is to promote philosophical activity by publishing innovative writings. It treats philosophy as philosophy. It does not have any prejudice for or against any specific mode of philosophizing. The classical Indian Philosophy and its impact on contemporary Indian thought have been engaging the attention of philosophers of world. A philosopher can do what a philosopher had done. Whatever philosopher did in the past was made possible by his rational attitude, aspirations and norms. The dominant elite class of section manages to steer the society in the direction chosen by it only through a skilful employment of the basic beliefs in the field of philosophy. It is not possible to break away from time-honoured world view. The wine may change, but the bottle remains the same. The recent upsurge of interest in India's past is welcome trend.

This volume comprises the articles which prominently deal with classical Indian Philosophy. 'The Fading Boundaries of Analysis and Speculation in the Vivekacūọāmaṇi: An Argument Recognizing Advaita as a Philosophy in Praxis' by Walter Menezes aims to make a case in favour of Advaita as a philosophy than a theological enterprise. The aim of Vedāntic conception of Philosophizing is to attain legitimate destiny of human being. The fulfilment of human destiny lies in the realization of the absolute or utter freedom. Man cannot realize utter freedom on rational plane. Reason moves in the realm of duality between content and consciousness. The duality can be resolved in higher consciousness. The higher consciousness is spiritual realization of pure subjectivity. Freedom can be realized when the subject is completely dissociated from the object. Advaita Vedānta conceives that the real subject cannot be apprehended by reason. It is intuitive vision which fathoms the depth of ultimate reality.

Publisher's Note Springer Nature remains neutral with regard to jurisdictional claims in published maps and institutional affiliations.

Ramesh Chandra Sinha

rcsinha22@gmail.com

1 Patna, India 